\title{
Detection of Hepatitis B Virus Antigens in Paraffin-embedded Liver Specimens from the Amazon Region, Brazil
}

\author{
SRR Simonetti, HG Schatzmayr, OM Barth+, JP Simonetti
}

\author{
Departamento de Virologia, Instituto Oswaldo Cruz-Fiocruz, Av. Brasil 4365, 21045-900 Rio de Janeiro, RJ, Brasil
}

Hepatic viscerotomy of paraffin-preserved old specimens, collected in the period from 1934 to 1967, were analyzed by immunohistochemical assays to detect hepatitis $B$, hepatitis $D$, dengue and yellow fever virus antigens. The material belongs to the Yellow Fever Collection, Department of Pathology, Instituto Oswaldo Cruz, Rio de Janeiro, Brazil and the cases were diagnosed at that time according to clinical aspects and histopathological findings reporting viral hepatitis, yellow fever, focal necrosis and hepatic atrophy. From the 79 specimens, 69 were collected at the Labrea Region and the other 10 in different other localities in the Amazon Region. The five micra thick histological slices were analyzed for the presence of hepatitis B surface antigen (HBsAg) and hepatitis B core antigen (HBcAg) by immunoperoxidase technique. An immunofluorescence assay was applied to the detection of hepatitis D, yellow fever and dengue virus antigens. Nine (11.4\%) histological samples were HBsAg reactive and $5(6.3 \%)$ were HBcAg reactive. The oldest reactive sample was from 1934. Viral antigens related to the other pathologies were not detected in this study. Our results confirm that the methodology described may be used to elucidate the aetiology of hepatitis diseases even after a long time of conservation of the specimens.

Key words: hepatitis B virus - human liver - Amazon - Brazil

According to the World Health Organization, hepatitis $\mathrm{B}$ virus (HBV) carriers account for $5 \%$ of the world population. These potential infection transmitter individuals can evolve from the asymptomatic condition to a severe hepatic damage and even hepatocellular carcinoma. A similar HBV epidemiological distribution is observed for hepatitis D virus (HDV) that shares the obligatory association to HBV for its replication (Smedile et al. 1981). Frequently related to HBV chronic carriers and less frequently to the acute disease forms (Colombo et al. 1983, Rizzetto et al. 1983), HDV antigen was identified by immunohistochemical assays in liver cell nuclei of patients with chronic persistent or chronic active hepatitis, hepatitis B surface antigens (HBsAg-positive) (Rizzetto et al. 1977). In South America HDV infection was first observed in Venezuela as a severe and fulminant attack among Yucpa indians (Purcell $\&$ Gerin 1983) and in Colombia where $60 \%$ of the individuals studied were simultaneously HBV and HDV reactive (Ljunggren et al. 1984). In Brazil, the Amazon Region endemicity for both viruses is well known (Figueiredo Mendes et al. 1984, Fonseca et al. 1986, Simonetti et al. 1986) showing high prevalence pattern compared to the other parts of the world (Purcell \& Gerin 1983, Nordenfelt et al. 1983, Fonseca et al. 1988). This region is also endemic for yellow fever and it is thought whether another human hepatitis viruses had been introduced in this area by human serum present in vaccines against yellow fever, since there are observations on the occurrence of icterus in England and in Brazil, following vaccination against yellow fever in the 1930s and 1940s decades (Findlay \& Mac Callum 1937, 1938, Soper \& Smith 1938, Fox et al. 1942). We included the

\footnotetext{
This work received financial support from the Conselho Naciona de Desenvolvimento Científico e Tecnológico (CNPq), Brazil. ${ }^{+}$Corresponding author. Fax: +55-21-2270.6397. E-mail: barth@ioc.fiocruz.br

Received 3 May 2001

Accepted 5 September 2001
}

dengue virus antigen research in this study, once the same pathological liver findings are observed in yellow fever and haemorrhagic dengue, such as hepatomegaly, focal visceral haemorrhages, focal necrosis, sinusoidal acidophilic bodies, Kupffer cell hypertrophy and portal tract mononuclear cell infiltration.

To observe the simultaneous HBV and HDV antigen frequency and to detect yellow fever and dengue viral antigens in histological sections we studied 79 hepatic samples by immunohistochemical assays. Hepatic viscerotomy samples belong to the Yellow Fever Collection (Department of Pathology, Instituto Oswaldo Cruz, Brazil) created in the 1930s decade from an agreement between Brazilian Government and the Rockefeller Foundation International Division to study yellow fever in Brazil.

\section{MATERIALS AND METHODS}

Material - Seventy-nine paraffin-embedded hepatic samples collected from 1934 to 1967 were analyzed. Sixtynine samples were from the Labrea Region, State of Amazonas and ten random samples were from other different localities in the same state. The cases were diagnosed at that time as viral hepatitis, yellow fever, focal necrosis or hepatic atrophy according to clinical aspects and histopathological findings.

Methods - Four or five micra thick paraffin-embedded histological sections were prepared for hepatitis B, hepatitis $\mathrm{D}$, yellow fever and dengue virus antigen detection by immunoperoxidase or immunofluorescence techniques. $\mathrm{HBsAg}$ and hepatitis B core antigens ( $\mathrm{HBcAg}$ ) were detected by the immunoperoxi-dase assay (Immuno Tag S Immunon-Lipshaw Corporation). Paraffin sections were deparaffinated and treated with $90 \%$ and $85 \%$ ethyl alcohol solutions followed by $10 \%$ ammonium hydroxide solution. To block endogenous peroxidase, sections were incubated with 3 to $10 \%$ hydrogen peroxidase solution for 5 min. Sections were then incubated with peroxidase/antiperoxidase conjugate, stained with hematoxylin solution ( $1 \mathrm{~min}$ ) and treated with $0.2 \%$ ammonium hydroxide solution. The reaction colour was developed after 3-amino-9ethylcarbazole substrate addition. Positive HBsAg and 
$\mathrm{HBcAg}$ controls were included for every batch. HDAg was detected by the immunofluorescence assay as follows: $5 \mu \mathrm{m}$ thick paraffin-embedded sections were deparaffinated, rehydrated and digested with $0.1 \%$ protease solution (type XXVII Sigma) in Tris- $\mathrm{HCl} 0.5 \mathrm{M} \mathrm{pH} 7.4$ for $2 \mathrm{~h}$ at $37^{\circ} \mathrm{C}$ or $0.05 \%$ trypsin (Difco) in phosphate buffered saline $\mathrm{pH} 7.4$ for $10 \mathrm{~min}$ at $37^{\circ} \mathrm{C}$. Digested sections were incubated at room temperature for $30 \mathrm{~min}$ with FITCanti HD conjugate diluted 1:100 in PBS pH 7.4. Yellow fever and dengue virus antigens were tested by immunofluorescence (Huang et al. 1976, Walker \& Cain 1978, Schatzmayr et al. 1984, Barth et al. 1988): $4 \mu \mathrm{m}$ thick paraffin sections were deparaffinated, rehydrated and digested with $0.1 \%$ trypsin with $0.1 \% \mathrm{CaCl}_{2}$ solution in $\mathrm{PBS} \mathrm{pH} 7.8$ for $2 \mathrm{~h}$ at $37^{\circ} \mathrm{C}$. Digested sections were incubated at $37^{\circ} \mathrm{C}$ for 30 min with FITC-conjugated yellow fever positive simian serum diluted at 1:20 in PBS $\mathrm{pH}$ 7.2. Flavivirus hyperimmune ascitic fluid obtained from mouse was used to detect dengue virus antigen. After washing sections were mounted with buffered glycerol and examined at the UV microscope. Four controls were used for yellow fever virus detection: not infected Vero cells, yellow fever virus (17D strain)-infected Vero cells, not infected liver cells and HBV-infected liver cells. Aedes albopictus C6/36 infected cell line was included as positive control for dengue virus detection.

\section{RESULTS}

Nine $(11.4 \%)$ of 79 hepatic samples were HBsAg-reactive and $5(6.3 \%)$ were HBcAg-reactive by immunoperoxidase assay ( 2 of them showed reactivity for both viral markers). HDAg was detected in none of these reactive samples. $\mathrm{HBsAg}$ and $\mathrm{HBcAg}$ were more frequently seen in samples from people at lower ages since in both groups examined (male and female) we had a higher number of samples from persons under 21 years old. Two samples showing simultaneous $\mathrm{HBsAg}$ and $\mathrm{HBcAg}$ reactivity were from boys agged 2 and 6 years. Chronological distribution of viral markers detected in this study showed that old preserved-paraffin liver samples are still suitable for viral markers detection by immunoperoxidase assay. The results are shown in the Table.

An exclusive cytoplasmic HBsAg localization and an exclusive nuclear $\mathrm{HBcAg}$ localization were observed by immunoperoxidase assay. The results are shown in Figs $1-4$.

Yellow fever and dengue virus antigens were seen in none of the 79 hepatic samples by immunofluorescence assay.

\section{DISCUSSION}

The Labrea Region, State of Amazonas, shows a high HBV endemical level (Figueiredo Mendes et al. 1984, Fonseca et al. 1988); this was an important point in sample selection and could have influence on the uneven age range distribution observed. Hepatitis B virus antigen detection in the liver tissue samples by immunohistochemical assays showed a cytoplasmic HBsAg and a nuclear $\mathrm{HBcAg}$ localization.

Only the HBsAg-reactive (9 of 79) and HBcAg-reactive (5 of 79) samples were analyzed for the presence of HDAg. None of them showed reactivity. The possible explanations for this are (1) HDV is mainly found in young adults and $71.3 \%$ of people analyzed in our study were children under 14 years old (Fonseca et al. 1988); (2) the immunofluorescence method had low sensitivity that could not detect HDV antigen in low level concentration samples; and (3) the more recent HDV introduction in this region, which would be
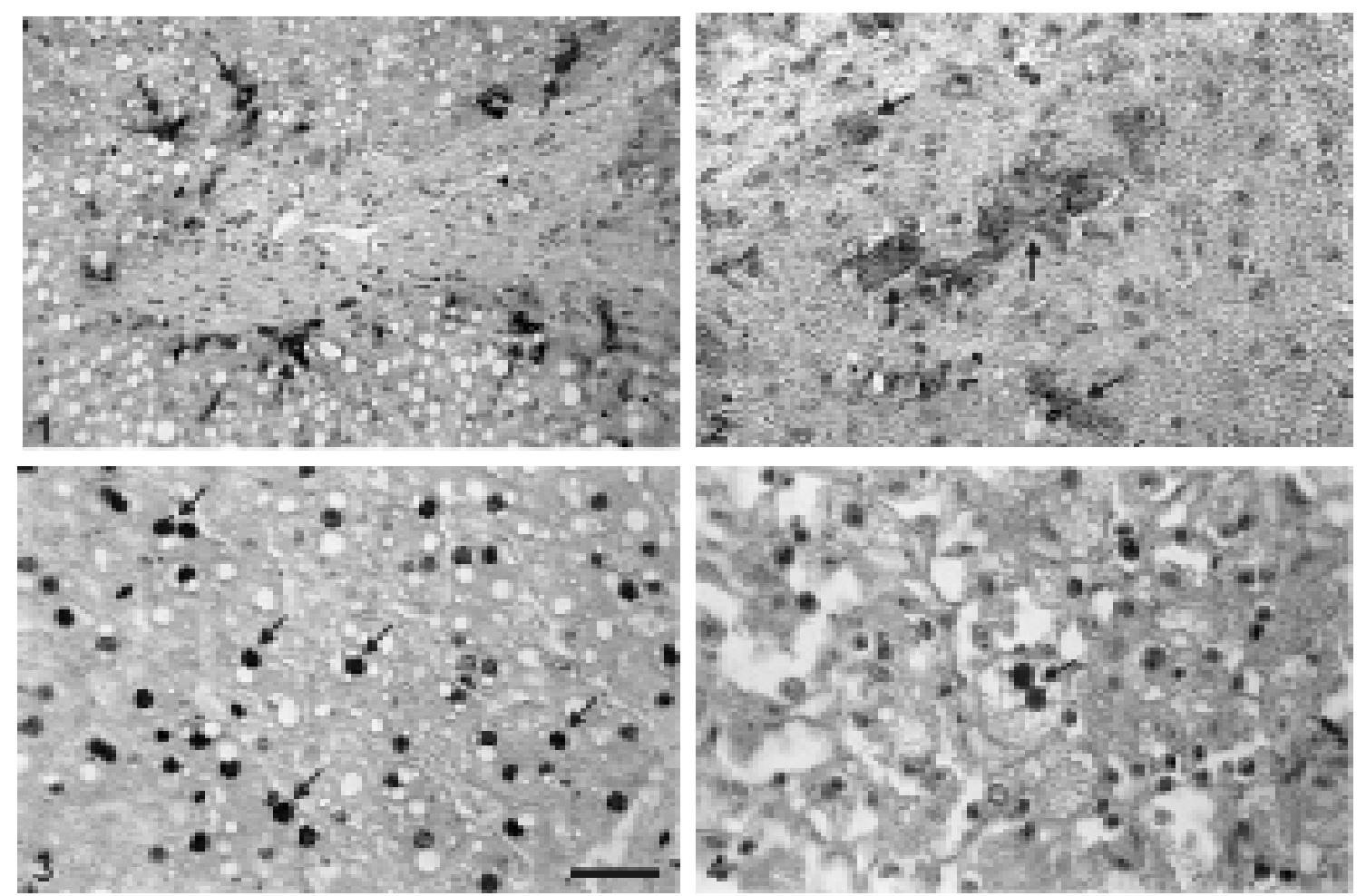

Figs 1, 2: hepatitis B surface antigens detected by positive immunoperoxidase assay inside hepatocytes cytoplasm (arrows). Figs 3, 4: hepatitis $\mathrm{B}$ core antigens detected by positive immunoperoxidase assay inside hepatocytes nuclei (arrows). Bar: Figs 1 , $3=140$ mm; Figs $2,4=35 \mathrm{~mm}$ 
TABLE

Data on the specimens positive for hepatitis B virus antigens

\begin{tabular}{lccll}
\hline Age & Sex & Date of collection & Origin & Original diagnosis \\
\hline $8 \mathrm{mo}$ & $\mathrm{F}$ & 1948 & Urucutuba & Viral hepatitis \\
$12 \mathrm{y}$ & $\mathrm{M}$ & 1950 & Benjamin Constant & Focal necrosis \\
$12 \mathrm{y}$ & $\mathrm{M}$ & 1950 & Benjamin Constant & Hepatic atrophy \\
$6 \mathrm{y}$ & $\mathrm{M}$ & 1967 & - & Viral hepatitis \\
$45 \mathrm{y}$ & $\mathrm{M}$ & 1950 & Lábrea & Viral hepatitis \\
$1 \mathrm{y}$ & $\mathrm{F}$ & 1952 & Lábrea & Viral hepatitis \\
$15 \mathrm{y}$ & $\mathrm{M}$ & 1963 & Lábrea & Hepatic atrophy \\
$9 \mathrm{y}$ & $\mathrm{M}$ & 1934 & Lábrea & Hepatic atrophy \\
$2 \mathrm{y}$ & $\mathrm{M}$ & 1942 & Lábrea & Hepatic atrophy \\
$54 \mathrm{y}$ & $\mathrm{F}$ & 1945 & Lábrea & Hepatic atrophy \\
$5 \mathrm{y}$ & $\mathrm{F}$ & 1946 & Lábrea & Hepatic atrophy \\
$3 \mathrm{y}$ & $\mathrm{M}$ & 1946 & Lábrea & Hepatic atrophy
\end{tabular}

subsequent to the analysis period of the samples (Fonseca et al. 1986, 1988, Simonetti et al. 1986).

The retrospective analysis evidenced HBsAg preservation in old histological samples. The oldest one, from 1934, was from a 9 year old boy from Labrea Region, Amazonas, with a negative yellow fever diagnosis.

All the 79 samples were analyzed for dengue and yellow fever virus antigen detection. The results were negative. This could be due to the low sensitivity of the method, as discussed for HDV (Fonseca et al. 1988). Alternatively, other viruses causing acute liver inflamation and necrosis, determining similar hepatic lesions to those described, or non-viral fatal infections such as malaria and leptospirosis, could be considered aetiological agents.

Our results confirm that the methodology described may be used to elucidate the aetiology of hepatitis diseases even after long time of conservation of the specimens. Retrospective studies of viral infection of the liver (Schatzmayr et al. 1984) were used in order to acquire a better knowledge of the natural history of these diseases and to may compare the data obtained with the actual distribution of hepatitis in the Amazon region.

\section{ACKNOWLEDGMENTS}

To Ms Itália B Kerr, Department of Pathology, Instituto Oswaldo Cruz, for delivery of specimens and related data. To Ms Ângela T Pinhão, Department of Virology, Instituto Oswaldo Cruz and to Dr Carlos Alberto Basílio, Pathology Service, Gafrée Guinle University Hospital, Rio de Janeiro, for technical assistance.

\section{REFERENCES}

Barth OM, Majerowicz S, Menasce LP, Schatzmayr HG 1988. Detection of viral infection by immunofluorescence in formalin-fixed tissues, pretreated with trypsin. Mem Inst Oswaldo Cruz 83: 207-212.

Colombo M, Cambieri R, Rumi MG, Rouchi G, Ninno E, Franchis R 1983. Long-term delta superinfection in hepatitis B surface antigen carriers and its relationship to the course of chronic hepatitis. Gastroenterology 85: 235-239.

Figueiredo Mendes T, Simonetti JP, Fonseca JCF, Simonetti SRR, Pittella AM, Schatzmayr HG, Ferreira LCL, Santos IM, Mexas PPF, Herbert BA 1984. O impacto da hepatite delta. Moderna Hepatologia (Boletim do Serviço de Hepatologia da Santa Casa do Rio de Janeiro) 9: 16-22.

Findlay GM, Mac Callum FO 1937. Note on acute hepatitis and yellow fever immunization. Trans R Soc Trop Med Hyg 31: 297-308.

Findlay GM, Mac Callum FO 1938. Hepatitis and jaundice associated with immunization against certain virus diseases.
Proc R Soc Med 31: 799-806.

Fonseca JCF, Simonetti SRR, Simonetti JP 1986. Hepatite por vírus delta. In O Borba Junior, Gastroenterologia, Medsi, Rio de Janeiro, p. 229-234.

Fonseca JCF, Simonetti SRR, Schatzmayr HG, Castejón MJ, Cesário ALO, Simonetti JP 1988. Prevalence of infection with hepatitis delta virus (HDV) among carriers of hepatitis B surface antigen in Amazonas State, Brazil. Trans $R$ Soc Trop Med Hyg 82: 469-471.

Fox JP, Manso C, Penna HA, Pará M 1942. Observations on the occurrence of icterus in Brazil following vaccination against yellow fever. Am J Hyg 36: 68-116.

Huang S, Minassian H, More JD 1976. Application of immunofluorescence staining on paraffin sections improved by trypsin digestion. Lab Invest 35: 383-390.

Ljunggren K, Patarroyo ME, Engle R, Purcell RH, Gerin JL 1984. Viral hepatitis and delta agent in Colombia. In GN Vyas, JL Dienstag, JH Hoofnagle (eds), Viral Hepatitis and Liver Disease, Grune \& Stratton, Orlando, p. 616.

Nordenfelt E, Hansonn BG, Al Nakib B 1983. Frequency of delta agent infections in Kuwait. J Infect Dis 143: 768-769.

Purcell RH, Gerin JL 1983. Epidemiology of the delta agent: an introduction. In M Rizzetto, G Verme, F Bonino (eds), Viral Hepatitis and Delta Infection, Alan R Liss, New York. p. 113-119.

Rizzetto M, Canese MG, Arico S, Crivelli O, Trepo C, Bonino F, Verme G 1977. Immunofluorescence detection of new antigen-antibody system (delta/anti-delta) associated to hepatitis B virus in liver and in serum of HBsAg carriers. Gut 18: 997-1003.

Rizzetto M, Verme G, Recchia S, Bonino F, Farci P, Arico S, Calzia R, Picciotto A, Colombo M, Popper H 1983. Chronic hepatitis in carriers of hepatitis B surface antigen with intrahepatic expression of delta antigen. Ann Intern Med 98: 437441.

Schatzmayr HG, Barth OM, Alencar AA 1984. Demonstração por imunofluorescência direta de antígenos do vírus da febre amarela em tecido hepático pré-tratado com tripsina. Mem Inst Oswaldo Cruz 79: 93-99.

Simonetti SRR, Fonseca JCF, Simonetti JP 1986. Vírus da hepatite delta. In O Borba Junior, Gastroenterologia, Medsi, Rio de Janeiro. p. 219-227.

Smedile A, Dentico P, Zanetti A, Sagnelli E, Nordenfelt E, Actis GC, Rizzetto M 1981. Infection with the delta agent in chronic HBsAg carriers. Gastroenterology 81: 992-997.

Soper FL, Smith HH 1938. Yellow fever vaccination with cultivated virus and immune and hyperimmune serum. Am J Trop Med 18: 111-134.

Walker DH, Cain BGA 1978. A method for specific diagnosis of Rocky Mountain spotted fever on fixed paraffin-embbeded tissue by immunofluorescence. J Infect Dis 137: 206-209. 
